\title{
Applications of bacterial endophytes and their advanced identification methodologies
}

\author{
R. Renugadevi*, M. P. Ayyappadas, V. Subha Priya, M. Flory Shobana, K. Vivekanandhan \\ Department of Biotechnology, Rathnavel Subramaniam College of Arts and Science Autonomous, Coimbatore, India.
}

\section{ARTICLE INFO \\ Article history: \\ Received on: January 05, 2021 \\ Accepted on: April 15, 2021 \\ Available online: November 10, 2021}

\section{Key words:}

Bacteria, endophytes,

phytohormones, phosphate

solubilization and nitrogen

fixation, siderophore production

\begin{abstract}
Endophytic bacteria found in all the plant that colonizes the internal tissues of their host plant and establish different relationships, such as symbiotic, commensalistic, mutualistic, and tophobiotic. The molecular basis of endophytic interactions is still not well understood. Endophytic bacteria improve plant growth under normal and difficult circumstances. They increase nutrient uptake, modify the plant growth, synthesis phytohormones, and secondary metabolites, also provide defense mechanism against pathogens and pests by hydrolytic enzymes with nutrient limitation. Endophytes has greatest phosphate solubilization potential and nitrogen fixation properties and produce siderophore compound in order to uptake Fe. This review focus on the isolation, screening, molecular identification by $16 \mathrm{SrRNA}$ sequencing and highlights of potential application of bacterial endophytes.
\end{abstract}

\section{INTRODUCTION}

Microorganisms in soil generate nutrients, such as phosphorous, nitrogen, oxygen, hydrogen, potassium, vitamins, amino acids, and trace elements promote growth and health of plants. Endophyte is an endosymbiont living inside the plants and release phytohormones and other secondary metabolites, which regulate growth and morphogenesis of plants in both direct and indirect ways. Phosphate solubilization and nitrogen fixation of endophytes promote soil fertility, siderophore compound enhance plant growth and act as biocontrol agent control pests and insects.

Endophytes are thriving in leaves, stems, roots, seeds, fruits, flowers that benefit plant growth. This review focuses on the applications of bacterial endophytes and their advanced identification methodologies. Several kinds of endophytes are colonized in living plants to adopt host plants against surrounding stresses. During last two decades, these endophytes have targeted for new

\footnotetext{
*Corresponding Author

Renugadevi, Department of Biotechnology, Rathnavel Subramaniam College of Arts and Science(Autonomous), Coimbatore, India.

E-mail: renugadevi@rvsgroup.com
}

bioactive compounds and secondary metabolites [1]. Endophytes colonize in plants tissue intra/intercellularly can benefit host plant without causing harmful disease, which supports plant growth in regular and challenging conditions [2]. Endophytes such as fungi, bacteria, or actinomycetes associated within plants studied almost until now. Colletotrichum sp., Enterobacter sp., Phomopsis sp., Cladosporium sp., Phyllosticta sp., etc are few commonly found endophytes [3]. It has been reported that Agrobacterium, Achromobacter, Bacillus, Acinetobacter, Brevibacterium, Pseudomonas, and Xanthomonas are some diversity of endophytic bacteria [4].

Plant limits endophytic growth to adapt in a gradual way to their living environments that produce a variety of compounds that are beneficial to plants development and protection [5]. Several compounds of endophytic bacteria establish steady symbiosis to adapt environmental conditions [2,6]. The bacterial endophytes are isolated from all types of plants such as from maize and bambusoid grasses $[7,8]$. From a single plant, different species of bacterial endophytes are also identified and reported [9]. Quorum sensing is the technique that differentiates endophytic bacteria from pathogen where the communication process is made by pathogenic bacteria by producing signal molecules called autoinducers to track the density of population [10]. 
There are certain components involved in different metabolic process, necessarily required for the proper growth of agricultural crops. A phosphate which is present in chemical fertilizer becomes converted into insoluble forms by complexing with calcium ions, iron or aluminum. These insoluble phosphates converted into soluble forms by activity of many phosphates solubilizing bacteria. Indole acetic acid (IAA) is the most important plant hormone synthesized in meristematic tissues of plants among PGPR. IAA involved in differentiation of cells and tissues including lateral bud formation and tropism responses. siderophores also control the growth of plant pathogens through biological control mechanisms [11].

Siderophores are low molecular weight compound, metalchelating agents of catecholates, hydroxamates, and carboxylates produced by several endophytic bacteria. Most of siderophore compounds scavenge iron, aid in the acquisition of mineral nutrients for micro-organism and shield them from pathogens by acting as virulence factors [12].

Nitrogen fixing process takes place to convert atmospheric nitrogen reduced to ammonia with help of nitrogense enzyme. Since they are sheltered within plant tissues, nitrogen-fixing endophytic bacteria have an advantage over their rhizospheric equivalents because they face less competition and can make fixed nitrogen accessible to plants directly [13].

\section{ISOLATION AND SCREENING OF ENDOPHYTIC BACTERIA}

A healthy plant samples (leaves, stems, or roots) were collected in clean plastic bags to the laboratory and use for the further experimental purpose [14]. Surface sterilization was carried out to remove epiphytes and other dirt substances of the sample. Plant tissues were treated with oxidant or sterilizing agent followed by a sterile rinse for 3-4 times $[15,16]$. Freshly collected leaves were washed under slow running tap water for 10-15 minutes followed by washing in Tween 20 for 1 minute and rinsed with sterile distilled water for 3 times in the laminar airflow cabinet. Sterilizing agents like Sodium hypochlorite: $1 \%-2 \%$ for $4-10$ minutes [17], ethanol: $70 \%$ for 30 seconds -4 minutes [18], hydrogen peroxide [15] and mercuric chloride $0.05 \%-0.2 \%$ for $2-5$ minutes are commonly followed for sterilization $[19,20]$. The validation of the above said sterilization procedure was carried out by imprinting the plant tissue onto nutrient media and fumigationbased process prevents microbial contamination [21,22].

The choice of growth medium facilitates the culturing endophytes. The sterilized plant samples are cut into $0.5 \mathrm{~cm}$ segments, macerated in sterile saline solution by a homogenizer. One milliliter of this sample is serially diluted from $10^{-1}$ to $10^{-10}$, and $0.1 \mathrm{ml}$ was spread onto nutrient agar (NA), Luria-Bertani agar, and tryptone soya agar media and incubated for 24-48 hours at room temperature [23]. It is advisable to use an antifungal agent, nystatin of $30 \mu \mathrm{g} /$ $\mathrm{ml}$ of each to suppress fungal growth [14]. After 24-48 hours from the bacterial cultures, select the morphologically different bacterial colonies and are repeated streaking to be followed to achieve bacterial isolates. The pure cultures isolated in NA are maintained at $4^{\circ} \mathrm{C}$ till further used.

\subsection{Biochemical and Morphological Identification of Endophytic Bacteria}

The previous reports stated that bacterial colonies are differentiated based on morphological colony characters such as Colony characters, Shape, Colour, Margine, Opacity, Elevation, Consistency, Gram characters and Motility follows the standard laboratory techniques [24]. The microscopic examination can be performed with the oil immersion objective of the bright field microscope. The biochemical tests such as Catalase, Oxidase, Urease, Coagulase, Starch hydrolysis and IMViC tests are used to check the biochemical character of endophytic bacteria using standard manual [25].

\subsection{Molecular Identification of Bacterial Endophytes}

For molecular identification, 16rRNA Sequence analysis provides accurate result by using BLAST algorithms [http://www.ncbi. nlm.nih.gov]. Clustal X (version 1.81) is used to conduct multiple sequence alignment. It was reported that bacterial identifications done to be based on 16S rRNA gene sequence similarity [26,27]. Clustering analysis such as neighbors joining phylogenetic trees analysis can be generated using sequence data from gene banks for strains [28].

\section{POTENTIAL APPLICATIONS OF ENDOPHYTES}

Endophytes possess several potential applications such as it can fix atmospheric nitrogen, synthesize siderophores compound, secretes several phytohormones, solubilize phosphorus, and synthesis enzymes that can induce different growth stages and development (Fig. 1).

\subsection{Plant Growth-Promoting Endophytes}

Phytohormones enhance growth and development of plants that can adapt to environmental stress by altering their hormone levels

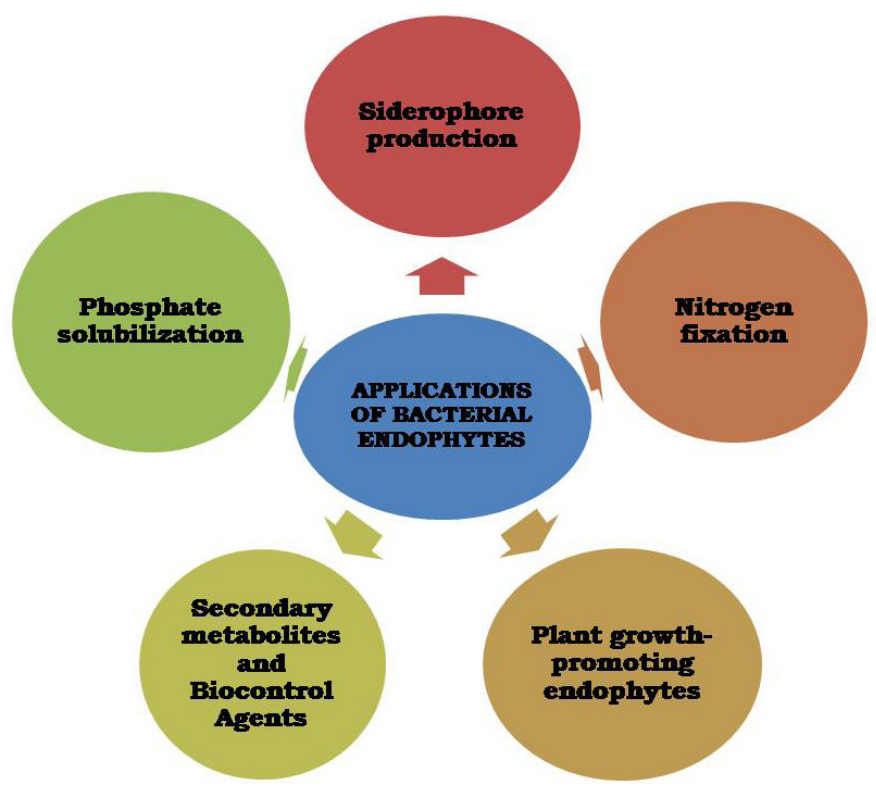

Figure 1: Potential applications of endophytes. 
[29]. Since plant hormones act as regulators in development and response of plants, but low-level secretion of hormone in plants shows less response. In that case, phytohormones of endophytic bacteria can regulate the endogenous plant hormone levels and eventually influence plant growth and development in many aspects [30]. Auxin secreted by endophytic bacteria within the plant to stimulate root growth that induces the formation of adventitious roots, lateral, and root hairs [31]. In plant cells, Auxin plays a variety of roles, including regulating rigidity and cell wall composition to aid cell elongation. It also protects the plant by increasing the resistance against external stress [32]. Endophytes were the most predominant producer of cytokinin. Cytokinins not only produced by pathogenic and beneficial microorganism but also secreted by endophtic bacteria of plants. It used to increase the shelf life of vegetables, cut-flowers, fruits, stimulate apical dominance of roots, influences the seed germination, leaf senescence, and inducing plant immunity [33]. Endophytic bacteria liberate gibberellins and Auxins, both are involved in seed germination, growth of leaf, flower, stem, root, and fruit [34]. Ethylene is a signaling molecule between bacteria and plants for fruit ripening, plant development, sex determination, and when secretes at a higher level, can reduce plant performance [35]. Several endophytic and rhizospheric bacteria, including Azotobacter, Azospirillum, Bacillus, and Pseudomonas produce IAA through tryptophan-dependent or tryptophan-independent pathways [36].

\subsection{Nitrogen Fixation and Phosphate Solubilization}

Nitrogen acts as nutritional factor for the plants. It was reported that endophytic bacterial inoculants supply nitrogen for growth and development through biological nitrogen fixation [37]. Bacillus, Fusarium, Pseudomonas, Rhizobium, and Klebsiella are few promising endophytic bacteria supply nitrogen requirement in leguminous and non-leguminous plants [38]. In agricultural sector, an endophytic bacterium fixes nitrogen and serves as alternative for chemical fertilizers [34]. Nitrogen fixing capability of endophytic bacteria is confirmed by acetylene reduction assay [39]. Endophyticbacteria like Azospirillum spp., Herbaspirillum, and Azoarcus spp. are fixes nitrogen in non-legume plants [40].

Phosphate solubilizing bacterial inoculants converts insoluble phosphorus to soluble form for high plant yields [41]. Endophytic and rhizospheric bacteria have been shown to increase phosphorus usage efficiency in wheat cultivars with deficient soil [42]. The use of synthetic phosphate fertilizers is heavily reliant on farming activities. However, the cost of synthetic fertilizers is related to negative effect on human and environment. Phosphate solubilization of microbial communities such as including fungi and bacteria are alternative source for synthetic fertilizer [43].

\subsection{Siderophore Production}

Endophytes secreting low molecular weight iron binding siderophores molecule for plant growth. The universal method adopted to detect siderophore production in microorganisms is Chrome azurol $\mathrm{S}$ agar plate assay. Cross-feeding assays are alternative tool for detecting and characterizing wild as well as mutant bacteria-produced siderophores [44]. Microorganisms to produce siderophores are natural iron chelating agents either reduces or prevents chlorosis in plants. It is claimed that Arnow and Csaky's tests were used to determine the levels and types of siderophores [45]. Moreover, siderophores of bacteria scavenge the soil iron from pathogens. Endophytic fungi of Penicillium chrysogenum have been found to secrete Fe3+ scavenging siderophore [46]. It was reported that iron was needed for metabolic process and proliferation of cell in biosynthesis of nucleotide, production of energy and as cofactor in electron transfer process [47].

\subsection{Secondary Metabolites and Biocontrol Agents}

Endophytes are reservoirs of secondary metabolites that secure anticancer antimicrobial, anti-insect, and other properties [48]. Many fungal and bacterial endophytes produce secondary metabolites, having antifungal, antibacterial, and insecticidal properties that prevent plant pathogens [49]. Biocontrol agents secreted by endophytic bacteria control or stop the entry of pathogen and infection [50]. To increase pathogen resistance, endophytes induce two forms of induced resistance such as systemic acquired resistance induced systemic resistance [51]. It was reported that endophytic bacteria colonized through plant tissue into vegetative and reproductive organs of plants. Plants with prior inoculation with endophytes reduce the diseases of fungal, viral, and bacteria and prevent insects and nematodes attack [52-54].

\section{CONCLUSION}

Endophytic bacteria are present in the internal tissues of their host plant and form a mutualistic or symbiotic relationship. They promote plant growth by secreting secondary metabolites and phytohormones. It is believed that endophytes solubilize phosphate and fix nitrogen. Most endophytes produce siderophore to provide iron for improved growth and yield, as well as to control plant disease pathogens and insects as a biocontrol agent. A report says that endophytic bacteria remove soil contaminants by phytoremediation. The isolation and molecular screening of bacterial endophytes from plant tissues were the subjects of this review article, which also highlighted five important applications of endophytic bacteria in agriculture and medicine. This review focuses the essential highlight of the previous work, current research, and new methodology associated with endophytic microorganisms to evoke knowledge of the research for the future perspective.

\section{AUTHOR CONTRIBUTION}

R. Renugadevi and M. P. Ayyappadas developed the idea concept and design of this work. M. Flory Shobana and V. Subha Priya done data acquisition, R. Renugadevi, K. Vivekanandhan, R. Renugadevi and K. Vivekanandhan analysis the data interpretation, R. Renugadevi draft this manuscript and find the technical support under the Supervision of M. P. Ayyappadas and also carried out the revision of this study and approved finally.

\section{FUNDING}

There is no funding to report. 


\section{CONFLICT OF INTEREST}

All the authors of this study declare that no conflicts of interest exist.

\section{ETHICAL APPROVALS}

This study does not involve experiments on animals or human subjects.

\section{REFERENCES}

1. Tadych M, White JF. Endophytic microbes, In: Thomas M (ed.) Schmidt, encyclopedia of microbiology, Academic Press, Cambridge, MA, pp 123-36, 2019.

2. Afzal I, Shinwari ZK, Sikandar S, Shahzad S. Plant beneficial endophytic bacteria: mechanisms, diversity, host range and genetic determinants. Microbiol Res, 2019;221:36-49.

3. Nair DN, Padmavathy S. Impact of endophytic microorganisms on plants, environment and humans. Sci World J 2014;1-11.

4. Sun $\mathrm{H}, \mathrm{He} \mathrm{Y}, \mathrm{Xiao} \mathrm{Q}, \mathrm{Ye} \mathrm{R}$, Tian Y. Isolation, characterization and antimicrobial activity of endophytic bacteria from Polygonumcuspidatum. Afr J Microbiol Res 2013;7:1496-504.

5. Nazir A, Rahman HA. Secrets of plants: endophytes. Int J Plant Biol 2018;9(1):43-6.

6. Lee S, Flores-Encarnación M, Contreras-Zentella M, Garcia-Flores L, Escamilla JE, Kennedy C. Indole-3-acetic acid biosynthesis is deficient in Gluconacetobacterdiazotrophicus strains with mutations in Cytochrome C biogenesis genes. J Bacteriol 2004;186(16):538491

7. Kiarie S, Nyasani JO, Gohole LS, Maniania NK, Subramanian S, Impact of fungal endophyte colonization of Maize (Zea mays L.) on induced resistance to thrips-and aphid-transmitted viruses. Plants 2020;9(4):416.

8. ALKahtani MD, Fouda A, Attia KA, Al-Otaibi F, Eid AM, Ewais $\mathrm{EE}$, et al. Isolation and characterization of plant growth promoting endophytic bacteria from desert plants and their application as bioinoculants for sustainable agriculture. Agronomy 2020;10(9):1325.

9. Afzal I, Shinwari ZK, Sikandar S, Shahzad S. Plant beneficial endophytic bacteria: mechanisms, diversity, host range and genetic determinants. Microbiol Res, 2019;221:36-49.

10. Firdous J, Lathif NA, Mona R, Muhamad N. Endophytic bacteria and their potential application in agriculture: a review. Indian J Agric Res 2019;53(1): 1-7.

11. Singh TB, Sahai V, Ali A, Prasad M, Yadav A, Shrivastav P, et al. Screening and evaluation of PGPR strains having multiple PGP traits from hilly terrain. J Appl Biol Biotechnol 2020;8(04):38-44.

12. Maheshwari R, Bhutani N, Suneja P. Screening and characterization of siderophore producing endophytic bacteria from Cicer arietinum and Pisum sativum plants. J Appl Biol Biotechnol 2019;7:7-14.

13. Gupta G, Panwar J, Akhtar MS, Jha PN. Endophytic nitrogen-fixing bacteria as biofertilizer. Sustainable agriculture reviews. Springer Dordrecht, Netherlands, pp 183-221, 2012.

14. Nawed A, Chandra R. Endophytic bacteria: optimizaton of isolation procedure from various medicinal plants and their preliminary characterization. Asian J Pharm Clin Res 2015;8(4):233-8

15. Saldierna Guzmán JP, Nguyen K, Hart SC. Simple methods to remove microbes from leaf surfaces. J Basic Microbiol 2020;60(8):730-4

16. Zinniel DK, Lambrecht P, Harris NB, Feng Z, Kuczmarski D, Higley P, et al. Isolation and characterization of endophytic colonizing bacteria from agronomic crops and prairie plants. Appl Environ Microbiol 2002;68:2198-208

17. Nxumalo CI, Ngidi LS, Shandu JS, Maliehe TS. Isolation of endophytic bacteria from the leaves of Anredera cordifolia CIX1 for metabolites and their biological activities. BMC Complement Altern Med 2020;20(1):1-11.
18. Shukla S, Wahla V. Influence of different sterilizing methods on isolation endophytic bacteria from Rauvolfia serpentina. Pharm Innov J 2019;8:38-41.

19. Oo KT, Oo KS, Mon Y. Establishment of efficient surface sterilization protocol on different types of field grown strawberry explants (Fragaria x ananassa Duch.). J Sci Innov Res 2018;7(3):70-4.

20. Singh CR. Review on problems and its remedy in plant tissue culture. Asian J Biol Sci 2018;11(4):165-72.

21. Bello OA, Esan EB, Obembe OO. Establishing surface sterilization protocol for nodal culture of Solanecio biafrae. IOP Conf Ser 2018;210(1):012007.

22. Sivanesan I, Muthu M, Gopal J, Tasneem S, Kim DH, Oh JW. A fumigation-based surface sterilization approach for plant tissue culture. Int J Environ Res Public Health 2021;18(5):2282.

23. Ramalashmi K, PrasannaVengatesh K, Magesh K, Sanjana R, Siril Joe $\mathrm{S}$, Ravibalan K. A potential surface sterilization technique and culture media for the isolation of endophytic bacteria from Acalyphaindica and its antibacterial activity. J Med Plants Stud 2018;6(1):181-4.

24. Bergey DH, Holt, JG. Bergey's manual of determinative bacteriology. Lippincott Williams \& Wilkins, Philadelphia, PA, 2000.

25. Varghese N, Joy PP. Microbiology laboratory manual. Pineapple Research Station, Kerala Agricultural University, Vazhakulam, India pp 1-77, 2014.

26. Sarjono PR, Hazrina QH, Saputra A, Mulyani NS, Aminin AL, Ngadiwiyana, et al. Isolation, characterization, and identification of endophytic bacteria by $16 \mathrm{~S}$ rRNA partial sequencing technique from leaves of carica papaya and its potential as an antioxidant. AIP Conf Proc 2020;2237(1):020-53.

27. Halda-Alija L. Incidence of antibiotic-resistant Klebsiella pneumoniae and Enterobacter species in freshwater wetlands. Lett Appl Microbiol 2004;39(5):445-50.

28. Alsanie WF, Felemban EM, Farid MA, Hassan MM, Sabry A, Gaber A. Molecular identification and phylogenetic analysis of multidrugresistant bacteria using 16S rDNA sequencing. J Pure Appl Microbiol 2018;12(2):489-96.

29. Bhattacharyya PN, Jha DK. Plant growth-promoting rhizobacteria (PGPR): emergence in agriculture. World J Microbiol Biotechnol 2012;28(4):1327-50

30. Foo E, Plett JM, Lopez-Raez JA, Reid D. The role of plant hormones in plant-microbe symbioses. Front Plant Sci 2019;10:1391.

31. Hilbert M, Voll LM, Ding Y, Hofmann J, Sharma M, Zuccaro A. Indole derivative production by the root endophytePiriformosporaindica is not required for growth promotion but for biotrophic colonization of barley roots. New Phytol 2012;196(2):520-34.

32. Awwad F, Bertrand G, Grandbois M, Beaudoin N. Auxin protects Arabidopsis thaliana cell suspension cultures from programmed cell death induced by the cellulose biosynthesis inhibitors thaxtomin A and isoxaben. BMC Plant Biol 2019;19(1):1-3.

33. Akhtar SS, Mekureyaw MF, Pandey C, Roitsch T. Role of cytokinins for interactions of plants with microbial pathogens and pest insects. Front Plant Sci 2020;10:1777.

34. Puri A, Padda KP, Chanway CP. Nitrogen-fixation by endophytic bacteria in agricultural crops: recent advances. In: Khan A, Fahad S (eds.). Nitrogen in agriculture - updates. Intech Jeneza Trdine Croatia, Rijeka, Croatia, pp 73-94, 2018.

35. Saleem M, Arshad M, Hussain S, Bhatti AS. Perspective of plant growth promoting rhizobacteria (PGPR) containing ACC deaminase in stress agriculture. J. Med. Plants Stud. 2007;34(10):635-48.

36. Bhutani N, Maheshwari R, Negi M, Suneja P. Optimization of IAA production by endophytic Bacillus spp. from Vigna radiata for their potential use as plant growth promoters. Isr J Plant Sci 2018;65(12):83-96.

37. Santos ML, Berlitz DL, Wiest SL, Schünemann R, Knaak N, Fiuza LM. Benefits associated with the interaction of endophytic bacteria and plants. Braz Arch Biol Technol 2018; 61:1-11. 
38. Rana KL, Kour D, Kaur T, Devi R, Yadav AN, Yadav N, et al. Endophytic microbes: biodiversity, plant growth-promoting mechanisms and potential applications for agricultural sustainability. Antonie Van Leeuwenhoek 2020;113:1075-107.

39. Das S, De TK. Microbial assay of N2 fixation rate, a simple alternate for acetylene reduction assay. MethodsX 2018;5:909-14.

40. Desbrosses GJ, Stougaard J. Root nodulation: a paradigm for how plant-microbe symbiosis influences host developmental pathways. Cell Host Microbe 2011;10(4):348-58.

41. Walia A, Guleria S, Chauhan A, Mehta P. Endophytic bacteria: role in phosphate solubilization. In Annapurna K, Maheshwari DK (ed.). Endophytes: crop productivity and protection. Springer, Cham, Switzerland, pp 61-93, 2017.

42. Emami S, Alikhani HA, Pourbabaee AA, Etesami H, Motasharezadeh B, Sarmadian F. Consortium of endophyte and rhizosphere phosphate solubilizing bacteria improves phosphorous use efficiency in wheat cultivars in phosphorus deficient soils. Rhizosphere 2020;14(1):100196.

43. Mehta P, Sharma R, Putatunda C, Walia A. Endophytic fungi: role in phosphate solubilization. In Singh BP (ed.). In advances in endophytic fungal esearch. Springer, Cham, Switzerland, pp 183-209, 2019.

44. Himpsl SD, Mobley HL. Siderophore detection using chrome azurol $\mathrm{S}$ and cross-feeding assays. In: Pearson M (ed.). Proteus mirabilis Methods in Molecular Biology 2019.p. 97-108.. Humana, New York, NY, pp 97-108, 2019.

45. Ferreira CM, Vilas-Boas Â, Sousa CA, Soares HM, Soares EV. Comparison of five bacterial strains producing siderophores with ability to chelate iron under alkaline conditions. AMB Express 2019;9(1):1-2.

46. Chowdappa S, Jagannath S, Konappa N, Udayashankar AC, Jogaiah S. Detection and characterization of antibacterial siderophores secreted by endophytic fungi from Cymbidium aloifolium. Biomolecules 2020;10(10):1412.

47. Voß B, Kirschhöfer F, Brenner-Weiß G, Fischer R. Alternaria alternata uses two siderophore systems for iron acquisition. Sci Rep 2020;10(1):1-10.
48. Gouda S, Das G, Sen SK, Shin HS, Patra JK. Endophytes: a treasure house of bioactive compounds of medicinal importance. Front Microbiol 2016;7:1538.

49. Gunatilaka AAL. Natural products from plant-associated microorganisms: distribution, structural diversity, bioactivity, and implications of their occurrence. J Nat Prod 2006;69(3):509-26.

50. Haas D, Defago G. Biological control of soil-borne pathogens by fluorescent pseudomonads. Nat Rev Microbiol. 2005;3:307-19.

51. Kamle M, Borah R, Bora H, Jaiswal AK, Singh RK, Kumar P. Systemic acquired resistance (SAR) and induced systemic resistance (ISR): role and mechanism of action against phytopathogens. In Hesham AEL, Gupta VK, Upadhyay RS, Sharma GD, Manoharachary C (ed.). Fungal biotechnology and bioengineering. Springer, Cham, Switzerland, pp 457-70, 2020.

52. Latha P, Karthikeyan M, Rajeswari E. Endophytic bacteria: prospects and applications for the plant disease management. In Ansari RA, Mahmood I (ed.). Plant health under biotic stress, Springer, Singapore, pp 1-50, 2019.

53. Liu JM, Wang SS, Zheng X, Jin N, Lu J, Huang YT, et al. Antimicrobial activity against phytopathogens and inhibitory activity on Solanine in potatoes of the endophytic bacteria isolated from potato tubers. Front Microbiol 2020;11:570926.

54. Abro MA, Sun X, Li X, Jatoi GH, Guo LD. Biocontrol potential of fungal endophytes against Fusarium oxysporum $f$. sp. cucumerinum causing wilt in cucumber. Plant Pathol J 2019;35(6):598-608.

How to cite this article:

Renugadevi R, Ayyappadas MP, Subhapriya V, Floryshobana M, Vivekanandhan K. Applications of bacterial endophytes and their advanced identification methodologies. J Appl Biol Biotech 2021; 9(06):51-55. 